\title{
Living in the Past: Thebes, \\ Periodization, and \\ The Two Noble Kinsmen
}

\author{
Alex Davis \\ University of St. Andrews \\ St. Andrews, Scotland
}

For Thomas Warton, writing about Chaucer's Knight's Tale in his History of English Poetry in the later eighteenth century, the cultural distance that separated him from the Middle Ages was epitomized by that period's lack of historical awareness:

[W] e are hardly disgusted with the mixture of manners, the confusion of times, and the like violations of propriety, which this poem, in common with all others of its age, presents in almost every page. The action is supposed to have happened soon after the marriage of Theseus with Hippolita, and the death of Creon in the siege of Thebes: but we are soon transported into more recent periods. Sunday, the celebration of matins, judicial astrology, knights of England, and targets of Prussia, occur in the city of Athens under the reign of Theseus. ${ }^{1}$

Warton's comments in his seminal literary history — the first comprehensive account of the English poetic tradition as such — present an early instance of an idea that came to dominate much twentieth-century thinking about the difference between the Middle Ages and the Renaissance; namely, that while both periods display an engagement with the classical past, only in the latter case was it approached on its own terms. Chaucer is a medieval author precisely because he presents knights jousting in ancient Athens. By way of contrast, the Renaissance — or, latterly, the early modern period — is distinguished by a sense of its own epochal distinctiveness. ${ }^{2}$ In Peter Burke's pithy summation: "the Middle Ages never knew that they were the Middle Ages. . . . But the Renaissance was quite conscious of the fact that it was a Renaissance." Indeed, it was a Renaissance precisely because it was conscious of the fact. ${ }^{3}$ This historiographical tradition developed through the writ- 
ings of Theodore Mommsen, Herbert Weisinger, and (in particular) Erwin Panofsky, and it continues to influence interpretation to this day. ${ }^{4}$

It is also significant that Warton should pick out for comment Chaucer's allegedly inadvertent ascription of chivalric practice to an antique setting, since an overarching narrative about the death of chivalry is a second master trope that serves to structure our sense of the difference between the medieval and the early modern. In this reading, any early modern figure displaying an interest in the trappings of chivalry is a Don Quixote: a ludicrous anachronism, mechanically playing out the behavioral codes of a bygone age. (The epithet "quixotic," for instance, seems perpetually to be available as a way of describing someone like the Earl of Essex.) Chivalry, then, is quintessentially medieval, and the numerous early modern deployments of the chivalric were essentially decorative and superficial: all style and no substance. The thing itself was dead. ${ }^{5}$ For Warton, then, Chaucer displays his "medievalness," his lack of sophisticated historical consciousness, by giving us a chivalric Athens. The "Renaissance" author, by way of contrast, might be classified as such if he could be shown to be in possession of the acumen that successfully discriminates between a classical Athens and a medieval chivalry: the one being distinguished from the other in a distancing, classificatory maneuver that simultaneously positions both as belonging to a past against which the present can then define itself.

"The Middle Ages," wrote Erwin Panofsky, "had left antiquity unburied and alternately galvanized and exorcised its corpse. The Renaissance stood weeping at its grave and tried to resurrect its soul."6 Compare Gordon McMullan and David Matthews, introducing their collection of essays Reading the Medieval in Early Modern England. For them, the invocation of Chaucer in the prologue to William Shakespeare and John Fletcher's play The Two Noble Kinsmen is best understood as performing an act of historical mediation. It "raises the possibility both that the sleep of the spectral medieval past might not be as easy as [the author of the prologue] would wish and that the medieval continues not just to be read and received in his own day but also works to construct the ways in which it is read." 7 On the face of things, these two passages could not be more opposed. McMullan and Matthews's argument is that the prologue bears witness to the possibility of a sense of historical continuity, the medieval bleeding into the early modern, that is quite at odds with Panofsky's reading of the Renaissance sense of the past. And yet there are also similarities here. McMullan and Matthews's intuition, that the periodizing categories that they seek to undermine were both born from and comprehensively articulated within the latter period, 
rather than being retrospectively applied to it, means that their account necessarily reifies those categories - the medieval, the early modern even as it seeks to call them into question. Both interpretations are driven by an underlying logic of historical difference, of which their shared imagery of death is the sign.

This is an influential way of identifying what distinguishes the early modern as a period, and yet I would argue that this insistence on locating the birth of our modern periodizing categories in the early modern period itself ought to be challenged - particularly as regards the products of English literary culture of the sixteenth and seventeenth centuries, in which historical awareness of the kind Panofsky and McMullan and Matthews describe is far more unevenly distributed than this model might suggest it should be. The work of William Shakespeare, for instance, is in many respects quite notoriously unmarked by signs of historical difference (clocks and doublets in ancient Rome, and so forth). Shakespeare frequently writes about the Middle Ages. What he does not on the whole do is write about the period in a "medievalist" way. That is, we actually have very little sense that he is approaching the medieval as such, across an openly acknowledged cultural and historical divide.

Our modern period categories may have their origins in the Renaissance, but that does not mean these categories achieved their full elaboration then. We ought to suspect the ease with which we are capable of reading such periodization into early modern literature, particularly if we also have reason to believe that doing so might blind us to alternative constructions of the past that were also active at the same time. To return to McMullan and Matthews's example: The Two Noble Kinsmen is a seventeenth-century play of knightly love and combat, adapted from the Knight's Tale, set in the ancient world, in which a fourteenth-century author's voice is imagined to address the audience from the grave. Rather than processing the play's treatment of chivalry and history through an interpretative paradigm that seeks to locate the epochal distinctiveness of early modern culture in its own selfawareness as such, I propose just the opposite. My aim is to scrutinize those historical narratives - what we might call the "master tropes" — that constitute our sense of what it is to be "early modern" as opposed to "medieval"; and in so doing, I hope to call these categories into question in a slightly new way.

The Two Noble Kinsmen opens with a prologue that invokes the memory of the play's distinguished source and "noble breeder": 
a poet never went

More famous yet 'twixt Po and silver Trent.

Chaucer, of all admired, the story gives:

There constant to eternity it lives.

If we let fall the nobleness of this

And the first sound this child hear be a hiss,

How will it shake the bones of that good man,

And make him cry from under ground, "O fan

From me the witless chaff of such a writer,

That blasts my bays and my learned works makes lighter

Than Robin Hood"?8

For McMullan and Matthews, the point of the prologue of The Two Noble Kinsmen is to stage a form of historical awareness that is predicated on a sense of the difference of the past. And yet, perhaps the most immediately striking thing about these lines is just how lightly they historicize the figure of Geoffrey Chaucer. On the whole, the passage is remarkably uninflected by the kinds of medievalizing detail we might expect from it; compare the Gower of Pericles, whose stiffly rhyming contribution is explicitly framed as "a song that old was sung," addressed to "these latter times / When wit's more ripe."9 By contrast, in The Two Noble Kinsmen Chaucer is presented as above all grave and noble: a laureate poet, outfacing the best that Italy has to offer. He is presented, in fact, as something like an English Petrarch. ${ }^{10}$ Rather than having a figure here subject to the distancing action of a temporality that constantly carries him ever further away from the present moment, we get instead a resounding declaration that Chaucer's writing "lives," "constant to eternity." The significant conceptual division organizing the passage is not between medieval and Renaissance or early modern, or even between past and present. It is the division between popular and elite - or, as the prologue would have it, "noble" — cultural production. A relevant figure here would be the Chaucer depicted in the engraving that prefaces the account of his life in Thomas Speght's 1598 edition of his Workes, hung about with interlinked patterns of coats of arms that emphasize his genealogical proximity to knights, dukes, and even kings. ${ }^{11}$ The prologue's prosopopoeia of a Chaucer nervous about the dramatization of his work self-defensively enacts an anxiety about the place of the stage in early modern culture: is this to be a "famed work," worthy of posterity's approval, or is it nothing more than a tale of Robin Hood, simplistic, vulgar, and foolish?12 Only the applause of the audience can decide. 
The worry staged in the prologue of The Two Noble Kinsmen is that literary re-creation may prove nothing more than vulgar recreation. (We are presented, in fact, with a sort of inverted family romance: will the play prove a noble or a base issue?) It is striking, furthermore, how the issues canvassed in the prologue refuse to be contained there and continue to structure and inflect the action of the play itself. The prologue opens with an extended, and somewhat disconcerting, comparison between "new plays and maidenheads." 13 The play proper begins with a masque of Hymen, leading Theseus's wedding procession, which is interrupted by the three Theban queens. The first of these appeals to Theseus's "true gentility"; the second begs Hippolyta to hear her "as you wish your womb may thrive with fair ones"; the third directs Emilia to "the love of him whom Jove hath marked / The honour of your bed" (1.1.25-30). The echoes of the prologue establish the possibility of a self-referential subtext to the action. Through its representation of a scene of pleading and supplication, 1.1 focuses our sense of the play's own affective power, strikingly aligning it with female sexual experience and motherhood; and with its formalized, quasi-ceremonial patterning of the action, it seeks to identify the resources of the theater with the nobility of the persons represented on stage.

The three queens' plea is that they should be allowed to burn their husbands' bones and give them proper burial. "Think, dear Duke, think / What beds our slain kings have" cries the first, with pointed reference to Theseus's approaching wedding night (1.1.139-40). Won over, Theseus wages war on Creon, ruler of Thebes, in order that they may do so. We see the husbands' belated funeral rites in 1.5 , but not before the motif of the unquiet dead has reappeared in modified form, with the discovery on the field of battle of the bodies of Palamon and Arcite: "not dead . . . / Nor in a state of life" (1.4.24-25). Once again we might be reminded of the prologue, this time of its vision of a Chaucer whose bones will be shaken and whose dead body may begin to cry out in dismay if The Two Noble Kinsmen does not meet with a favorable reception. The first act of the play is rife with images of unburied bodies, of unquiet bones, and of the half alive, weirdly intertwined with a contrary strain of allusion that emphasizes new life and marriage. The effect may seem macabre (the masque of Hymen that opens the play proper sings of "Marigolds, on deathbeds blowing" [1.1.11]), but on the terms established by the prologue, we can see that their association is entirely logical: each describes the same process of literary creation, or re-creation. Even as the play urges itself on toward generation, it is necessarily consumed by the vision of a past that refuses to stay dead. 
The sense of what is at stake in this debate, over whether or not the marriage of learned "medieval" verse and a "modern" theatrical medium might give birth to a noble issue, is extended and clarified by the introduction of the "low" plot strand centering on the Jailer's Daughter. Act 2 opens with the Jailer discussing the legacy that will descend to his daughter on his death: the jail itself, untenanted by the nobility for which it was built ("though it be for great ones, yet they seldom come" [2.1.3]). Given its status as heirloom - passed down through a succession of owners from past to present - we are, I think, to understand the prison house itself as a possible image for the play, just as much as the noble wedding or the funeral pyre. That this is the case is further suggested by the conclusion of 2.1, in which Palamon and Arcite are led across the upper stage in shackles, and the Jailer's Daughter has to be told not to point at them. "It is a holiday to look on them," she cries. "Lord, the difference of men!" (2.1.55-56). Her fascination with the spectacle of social distinction, of "difference," naturalized in the aristocratic bodies of the Theban kinsmen, is identified with "holiday" pastime, anticipating the play's later staging of May games and morris dancing.

Both the prison and, by implication, the physical structure of the Blackfriars playhouse, onto which the architecture of the jail is imaginatively projected, figure here almost as vast machines for viewing, framing for a vulgar audience the spectacle of a refined and (literally) elevated nobility. And in the next scene, this thematics of spectatorship is neatly pulled inside out, as we watch Palamon and Arcite first converse with one another, and then turn their attention outwards as Emilia passes by with her waiting woman. The precise details of the staging of these scenes are unclear. In the Quarto text, Palamon and Arcite initially pass by "above," while the transition between scenes is managed as follows:

Iailor. Goe too, leave your pointing; they would not Make us their object; out of their sight.

Daughter. It is a holliday to looke on them: Lord, the Diffrence of men. Exeunt,

Scaena 2. Enter Palamon, and Arcite in prison.

Palamon. How doe you Noble Cosen?

When Emilia passes beneath the kinsmen's window, she is simply described as entering the stage, with no indication as to the relative positions of the 
actors. ${ }^{14}$ The most thematically pleasing staging, however, would surely have the kinsmen above viewing Emilia below: first seen, and then, from the same position, seeing. Following the eyeline (and pointing finger) of the Jailer's Daughter, the audience's attention is drawn up to the cell inhabited by Palamon and Arcite; in the following scene, the initial point of dramatic focus is relocated here as the kinsmen first converse and then look out of their window on Emilia, standing below where the Jailer's Daughter formerly observed them. The Jailer had assured his daughter that the young noblemen "would not make us their object" (2.1.53-54), and he was right: it is Emilia who provides a suitable focus for the aristocratic gaze. In this elegantly chiasmic structure of high and low, watchers and watched, the audience's attention passes into the prison house and is there turned inside out.

This scene directs our attention toward a larger point about the play, which is that The Two Noble Kinsmen is saturated with the language of seeing and being seen. Indeed, there is scarcely an event in the play that is not at some point referred to as an object of spectatorship. Consider, for example, the tournament that resolves the quarrel between the two noble Theban cousins. Emilia declares that she will not "taint mine eye / With dread sights it may shun" (5.5.9-10); were she forced to go, she would "wink" in order to avoid seeing bloodshed (5.5.18). Theseus, however, is insistent: "the knights must kindle / Their valour at your eye" (5.5.29-30). "Infinite pity," Hippolyta laments, "That four such eyes should be fixed on one / That two must needs be blind for' $t$ " (5.5.144-46). ${ }^{15}$ In such a context, it is entirely characteristic that a furious Palamon should have earlier described Arcite as "thou most perfidious / That ever gently looked" (3.1.36-37). By this, he presumably means to suggest that his cousin's gentility is only superficial. However, the phrase also speaks to the play's representation of looking as an activity intimately bound up with questions of "gentle" status.

The habit is both an extension and a partial inversion of the way early modern writers tended to define high rank in terms of its visibility to others. For Henry Peacham, "Nobilitie . . is nothing else then a certaine eminency, or notice taken of some one aboue the rest, for some notable act performed, bee it good or ill."16 William Bird, meanwhile, derives the word nobility from "Nosco, to know." "Vir nobilis idem est quod notus \& per omnia \& per omnis \& $c$. A Noble-man is he who is known."17 In Shakespeare and Fletcher's formulation, however, the act of looking becomes as prominent as that of being looked at. Furthermore, The Two Noble Kinsmen presents this visual activity as part of an integrated system that locks those of high and low status together even as it distinguishes between them. The play is 
notable for its repeated deployment of carefully wrought networks of verbal echoes that make it clear that the noble practice of visuality finds its counterpart in a vulgar politics of seeing. Thus, Pirithous's comment to Emilia, "Will you lose this sight?" (5.5.1), recapitulates the discussions of the tournament in the preceding scene, in which a Messenger warns the Jailer that he risks missing "the noblest sight / That e'er was seen" (5.4.100-101), and the Doctor declares that "I will not lose the sight" (5.4.104). Similarly, when the Jailer's Daughter comes to recount the stages by which she came to love Palamon, she begins, "First, I saw him" (2.4.7) — clearly an inversion of the imprisoned Palamon's claim of priority in love for Emilia, where he warns Arcite that "I saw her first" (2.2.161).

In The Two Noble Kinsmen, the inferior status of the nongentle is manifested through the hungry, grasping quality of their vision (we hear of a tanner's daughter who "must see the Duke" [2.3.47]; characteristically, the enjoyment he might derive from seeing her is not openly discussed). The noble characters, although no less avid for the most part, are nonetheless privileged in being able to experience far more complex combinations of visual activity and passivity. As Palamon says to Arcite of Emilia, "You are going now to look upon a sun / That strengthens what it looks on" (3.1.121-22). When Arcite says that he aspires always to "dwell in sight of her" (2.3.88), these two forms of enjoyment, of seeing and being seen, become grammatically indistinguishable.

An episode such as 2.1 might initially seem to stage a sense of the early modern playhouse in these terms as a vehicle for vulgar spectatorship, responding perhaps to the metatheatrical burden of the first act of the play by asking whether true nobility could ever really thrive in such unpropitious circumstances. However, as the action of the play slowly unfolds, so too our sense of the value that might inhere in the form of chivalric manhood embodied by Palamon and Arcite becomes ever more troubled. Certainly the fate of the Jailer's Daughter stigmatizes the fascination with such nobility as utterly perilous, if not in the event quite fatal. By now it should be no surprise to find that, as her role in the play becomes ever more prominent, she too is constituted as another node of theatrical self-consciousness: the shadowed memories of previous dramatic productions begin to fold themselves around her like a winding sheet, as she first is reported to have sung the song "Willow," and then to have attempted to drown herself, recalling the fates of Desdemona and Ophelia $(4.1 .80,95) .{ }^{18}$ Such moments refashion the Shakespearean literary achievement as an emblem of the early modern stage's selfplacement as "popular," abjectly enthralled by "the intemperate surfeit of [its] 
eye" (4.3.67) to the spectacle of an unattainable aristocratic virtue. ${ }^{19}$ We are presented with a thematics of vision that constantly frames itself: in The Two Noble Kinsmen the theater is developed into a form of optical device, a spatial structure, that self-reflexively makes visible the lines of sight that delineate early-seventeenth-century social relations.

It is a mark of how far this spectatorial detachment should have eaten into the play's representation of a chivalric aristocracy that by Act 4 the Jailer's friend can say of the conditions Palamon and Arcite accepted in order to preserve their lives that "They are honourable - / How good they'll prove, I know not" (4.1.30-31). Such a distinction, between the "honourable" and the "good," would have been nearly unthinkable earlier in the play. ${ }^{20}$ And correspondingly, Shakespeare and Fletcher's representations of popular cultural practice become ever more detailed and prominent as the play progresses. In 2.3, we encounter a group of countrymen who have abandoned their work to attend the games, and who are discussing the coming Maying; in 2.5, Arcite participates in the games, using his victory in the wrestling contest as a platform from which to assert his gentle status (echoes of Orlando in As You Like It); while 3.1 opens with the "noise and hollering" of "people a-Maying." Finally, in 3.5 we have the morris dance prepared by the country schoolmaster, adapted from Francis Beaumont's The Masque of the Inner Temple and Grey's Inn (1613). ${ }^{21}$ Even this scene, however, with its countryfolk, its references to "little Luce" and "bouncing Barbary," "freckled Nell," and "Cicely, the seamstress' daughter" (3.5.26-27, 45), points toward the fundamental impossibility of decoupling representations of "popular" entertainment from their elite counterparts in this play- not simply because the morris is played before Theseus and his court, but also because the masque would also seem to provide the source for the Athenian "games" that Arcite first hears about in 2.3. The effect is both to echo the masque versus antimasque, high versus low structure of similarity and difference that organizes the source, and at the same time to put it in question. ${ }^{22}$

The play's treatment of Beaumont's work seems somehow emblematic of its operations generally. The Two Noble Kinsmen offers itself up to the spectator as a theatrical experience constituted out of other forms of performance, whether these forms are directly represented, such as the morris dance, or whether they are presented as existing on the margins, such as the Athenian games and the concluding tournament that occur offstage. The play hybridizes and borrows, as if searching for the exact synthesis of existing cultural materials that might provide the authentic mirror both of its protagonists' noble rank and of the questionable status of the early modern 
stage. Prison house, funeral, morris dance, aristocratic tournament, noble performer, and vulgar spectator - all intricately double and echo one other as the play elaborates ever-increasingly complex inset analogues for the technologies of viewing that it demonstrates underpin its own existence as a specifically theatrical production.

What this implies is that far from providing a wedge that we might use to prize apart the medieval from the early modern, an interest in the imagery of knighthood actually forms a point of connection between the two periods. Certainly the armored knight became an increasingly irrelevant force on the sixteenth- and seventeenth-century battlefield (and the sheer historical unreality of The Two Noble Kinsmen is in this sense entirely appropriate). But even as the forces of the emergent state system were gradually marginalizing the militarized aristocracies of the Middle Ages, ideals of honor and chivalry retained a symbolic prominence in the early modern imagination. ${ }^{23}$ They did so because the complex of ideas and associations that had over the years grown up around the figure of the knight continued to play an emblematic role in relation to the hierarchies of rank and place and precedence that organized early modern social relations. The Two Noble Kinsmen describes a world in which, no matter how unreal - how artificial or even misguided - the spectacle of chivalry may ultimately seem to be, it remains an inescapable part of how high and low see each other.

It is not just that Shakespeare and Fletcher's play fails to differentiate itself from its literary and cultural heritage in the ways we might expect, however. The features examined above also serve to position The Two Noble Kinsmen within a tradition of writing that significantly frames the play's inability to escape the past, and in so doing again articulates a rather different vision of the relationship between medieval and early modern from that outlined at the start of this study. The insistent dualities we have been examining, the intricately woven nets of self-referentiality that structure the play's engagement with questions of popular culture, all place The Two Noble Kinsmen within a "medieval" tradition of Theban narratives, identified by Lee Patterson, of which Chaucer's Knight's Tale is the most famous example. For Patterson, in texts such as the Knight's Tale, Anelida and Arcite, and Lydgate's Siege of Thebes, "Thebanness" finds its expression in repeated motifs of doubling that in turn produce a very specific vision of the relationship between past and present: "a replicating history that preempts a linear or developmental progress." Endlessly feeding off each other, these Theban tales elaborate "a fatal recursiveness that undermines all progressivity upon which the 
ideals of secular history are based and condemns chivalric ambition, whether antique or modern, to an endless repetition." 24

Partly this quality is a reflex of the narrative content of the Theban legend itself, with its extraordinary proliferation of doubles: Eteocles and Polynices, Palamon and Arcite, the brothers-in-law Polynices and Tydeus, the sisters Argia and Deipyle, the two prophets Amphiarus and Tiresias, the multiple pairs of twins that populate the battlefields of Statius's Latin epic, the Thebaid - even, perhaps, the double source of Anelida and Arcite: "Stace, and after him Corynne" (21).25 Compounding these uncanny repetitions, we find in many of these narratives an added sense of the overlayering of different roles, of which Oedipus's double status as son of and husband to the same woman is only the most extreme and transgressive example; it is thus fitting that, at the end of the Knight's Tale, both Palamon and Arcite should in some sense win Emelye. But it is also relevant that Patterson should be describing a tradition in which these purely narrative features are elaborated into an additional array of reduplications, in the form of a thematics of literary creation and re-creation. ${ }^{26}$

Thus, Statius's twins on the battlefield are, appropriately enough, themselves a literary echo or doubling of the twin brothers dispatched by Pallas in Book 10 of Virgil's Aeneid. As D. C. Feeney notes, the Thebaid is a poem intensely concerned with its own belatedness in relation to previous epic literature. Developing as a "bloated and highly self-conscious adaptation of Virgil's delaying tactics in the last three books of the Aeneid, and of Lucan's in the first seven books of the Bellum Civile," the poem positions itself as the epic of digression, delay, and incompletion:

When they at last set off, the heroes are unable to progress even as far as a book before they are enmeshed in the narrative of Hypsipyle and the funeral games of Archemorus. The deceased infant's significant name spells out "Bringer of Doom" (Mopos, moros), but it also clearly denotes "Originator of Delay" (mora). ${ }^{27}$

That is, the poem's narrative paralysis is intimately linked to its own literary awareness. It stands as the semihumorous index of its sophistication, and offers a precedent for later authors to write themselves into a tradition of "Thebanness."

Chaucer's Anelida and Arcite relocates the choked narrative dynamics of the Theban legend to the realm of romantic love; it also absorbs into itself the self-referentiality of the Latin epic. The poem opens with an invo- 
cation of Mars, followed by a quotation from Statius, and then, amplifying that quotation, a description of the same triumphal procession that opens the Knight's Tale, at which point the narrator breaks off:

Let I this noble prince Theseus

Toward Athenes in his wey rydinge,

And founde I wol in shortly for to bringe

The slye wey of that I gan to write,

Of queen Anelida and fals Arcite. (45-49)

Only now are we to proceed to the tale of the abandonment of the "quene of Armony" by her Theban lover. But what we are not given is any overt indication of the connection between the victories of Theseus and the matter of Thebes; the war against Creon is never openly referred to here and the relevance of the triumphal march remains unexplained. At the point of transition between one section of the narrative and another, then, these are lines that, in their own "slye" grammatical uncertainty (Whose "wey" is referred to here, Chaucer's or Arcite's?) hold out the possibility of superimposing Chaucer's exceptionally indirect, even disjunctive approach to his ostensible subject matter onto the "double," "subtil" (87-88) seductions of the Theban Arcite, always one step ahead of his unfortunate lover.

Anelida and Arcite quotes Statius. The Knight's Tale opens with the same quotation - a double reference, therefore. Both adapt the Teseida, Boccaccio's adaptation of the Latin epic. Self-reference and allusion of this sort are an integral part of "Thebanness," and so it is entirely appropriate that when John Lydgate came to write his Siege of Thebes he should frame his narrative within the Chaucerian literary achievement, presenting his account of the fall of the city as the first tale of the return from Canterbury, just as the Knight's Tale was the first of the outward leg. ${ }^{28}$ And while its staunch and apparently uncomplicated insistence on the distinction between "trouthe" and "doubleness" (1778) might seem to place The Siege of Thebes as the simple child in this extended family of related narratives, its positioning in relation to the Canterbury Tales suggests that, on some level at least, Lydgate perfectly understands the vicious circle of Theban literary production.

In a collection such as Thomas Speght's 1602 edition of Chaucer's works, which also prints The Siege of Thebes (and which Shakespeare and Fletcher consulted in the composition of The Two Noble Kinsmen), one passes from the Knight's Tale, through the rest of the poems, to Lydgate's supplementary pilgrim's narrative - and from there back into the world of the Knight's 
Tale again, since Chaucer's narrative picks up where Lydgate's leaves off. ${ }^{29}$ It is symptomatic that Lydgate's poem should be characterized by a stubborn refusal to come to a conclusion. We are reminded toward the end that it was his "promys ... / But to reherce the destruccion / Of mighty Thebes shortly, and no more" (4605-7), and the narration indeed repeatedly emphasizes the completeness of the ruin of the city: Theseus "brente" its houses (4556); "nouzt was left but the soyle al bare" (4561); it is "to wyldernesse turnyd and desert" (4639). And yet, despite these repeated gestures toward finality, the poem continues to extend itself for over two hundred lines past the final battle, progressing through a series of clauses, generally beginning with the word and, that encompass reflections on the fate of Adrastus, the foundation of Rome, the horrors of war, its Luciferian origins, only to suddenly shift forward into a utopian vision of a time, indefinitely postponed, in which "the venym and the violence / Of strif . . / Shal be proscript and voided out of place" (4691-93). ${ }^{30}$ It is evident, in context, that this refers to nothing less than the end of time itself; we are being presented with eschatology, not history. As Scott-Morgan Stalker comments, although Lydgate's editors' identify an allusion in his closing paragraph to the wording of the peace treaty drawn up between England and France in 1420, "the final lines of the Siege articulate ... the despairing recognition that earthly kings will never act prudently or embrace peace, so it is futile to instruct them": the "destruccion," in short, of Lydgate's entire literary project in this poem. ${ }^{31}$

In their new work, Amy Appleford and Catherine Sanok both clearly demonstrate Shakespeare's formal inventiveness and intelligence revivifying existing traditions of representing the past. ${ }^{32}$ The Two Noble Kinsmen should be taken as further evidence in favor of the same point. "Thebanness" desperate, claustrophobic, almost endlessly self-referential - exists, I would argue, as an active literary context for Shakespeare and Fletcher's play. Both its invocation of a literary predecessor and its extraordinary language, at once passionate, highly wrought, and brutally elliptical, belong in this tradition, the relevance of which is underlined by the interpolation into the basic structure of the Chaucerian source of a scene (1.2) in which Palamon and Arcite discuss Creon's tyrannical abuses, and plan to leave Thebes, only for war to be declared. ${ }^{33}$ Here is another failed escape from the city, then, and when the action does relocate to Athens, the effect is less that of the emancipatory influence of a democratic regime than of a cancer metastasizing into a new organ of the same body politic.

The play concludes, almost inevitably, with more funeral rites, but here again the effect is complicated by a final example of the collocations 
of death and new life that constitute Shakespeare and Fletcher's distinctive contribution to the tradition we have been examining. In the Knight's Tale, Chaucer is careful to emphasize that a decent time elapses between death and marriage; the latter is only permitted once "By processe and by lengthe of certeyn yeres, / Al stynted is the moornynge" (I.2967-68). In The Two Noble Kinsmen, the two are collapsed together without due "processe." Even in Theseus's most dignified summing up, the indecorous proximity of Arcite's funeral and Palamon's marriage can barely be kept from view:

\section{A day or two}

Let us look sadly and give grace unto

The funeral of Arcite, in whose end

The visages of bridegrooms we'll put on

And smile with Palamon. (5.4.124-28)

"Let's go off," Theseus concludes, "And bear us like the time" (5.6.136-37). And yet the overall effect of these lines may well be to leave us unsure what time it is that is being represented here. Is it a time of mourning or of celebration? Certainly the effect is not unique to Shakespeare's late plays. The Winter's Tale in a sense pivots on the line "Thou metst with things dying, I with things new-born" (3.3.111-12). But in that play the Shepherd's words issue into a staging of Time himself, personified. Progress in The Two Noble Kinsmen is not so easily secured. We are in a sense left only where we began, with the uneasy juxtaposition of "new maidenheads" with a world of fire and smoldering bone, and with the still more disturbing sense that each represents a different side of the same coin. We are presented with a world in which nothing is ever quite complete, in which the work of mourning is, once again, unbegun. Perhaps, then, one might see in this scene one final moment of literary self-reference. For is it not Shakespeare's Hamlet above all that suggests to the modern mind that the "o'er-hasty" (2.2.58) conflation of funeral rites and wedding celebrations is unlikely ever to result in a past that will stay satisfactorily buried?34

Thebanness, for Lee Patterson, is structured around this poetics of incompletion. It presents "consciousness in medias res, burdened with a multiplicitous past but incapable of being subordinated to a controlling understanding that would allow for satisfactory closure." 35 Its paradigmatic movement may be encapsulated by the narration of Hypsipyle in Book 5 of the Thebaid. As Statius comments at its outset, "the unhappy love to talk and bring back old sorrows" (V.48), but when Hypsipyle has finished speak- 
ing, she finds that her narration has simply promoted disaster in the present. Theban narration is always historical: Statius opens by invoking Clio (I.41), while Anelida and Arcite describes itself as a song sung with "vois memorial" (18), and The Two Noble Kinsmen openly alludes to its literary antecedents. What none of these texts ever do, however, is to construct the sort of historical consciousness described by Friedrich Schiller, in which the past is experienced as an independent object of thought. "How few people," Schiller writes, "really know what the past is":

there can in fact be no past without a present, a present achieved by the disjunction [of our past] from ourselves. That person incapable of confronting his or her past antagonistically really can be said to have no past; or better still, he never gets out of his own past, and lives perpetually within it still. ${ }^{36}$

It is a historicism of this kind that underpins the tradition of reading (to quote Herbert Weisinger) "The Self-Awareness of the Renaissance as a Criterion of the Renaissance." What Thebanness suggests is a rather different construction of historical knowledge. We are presented with a literary tradition that produces forms of self-awareness that are grounded in a sense of the omnipresence of the past, but coupled with a relative lack of imaginative investment in a logic of historical difference. These are texts that refuse completely to distinguish themselves from the history they depict. It is a common structural feature that they should open by articulating a sense of the text as "past," often through the invocation of a literary predecessor; and yet this sense never opens out into considerations of historical progress or change, of the past as somehow fundamentally different from the present. On the contrary, their deepest tendency is to put historicity under pressure, not out of ignorance, but in the service of a tragic vision of human existence. As Patterson comments, "rather than seeking to recuperate antiquity in its otherness, an otherness that can then provide the terms by which a modern or Renaissance self can define itself, Chaucer" — and, one might add, the other authors who place themselves in this tradition - "is persistently, even painfully aware of the affiliations that bind together past and present into a seamless and finally inescapable web." Their subject is "the failure of classical history, and of the poets who are its historians, to provide an escape from history." 37

History, in Thebes, is a monster that endlessly swallows its own tail. In this tradition, the topos of the death of chivalry can never produce 
the forms of historical rupture that one might expect of it. Compare, for instance, the innumerable funeral pyres that burn throughout the work of Statius, of Chaucer, and of Shakespeare and Fletcher with the closing scenes of Malory's Morte Darthur, in which Sir Lucan surveys the field on which the flower of Arthurian chivalry has been cut down in the final battle against Mordred:

As he yode he saw and harkened by the moonelyght how that pyllous and robbers were com into the fylde to pylle and to robbe many a full noble knight of broches and bees and of many a good rynge and many a ryche juell. And who that were nat dede all oute, there thee slewe them for their harneys and their ryches.

The age of chivalry is over; the reign of the little people — of the petty, the vulgar, and the greedy - has begun, until the king comes again: "HIC IACET ARTHURUS, REX QUONDAM REXQUE FUTURUS."38

In Malory, the evocation of a universal death of knighthood articulates a sense of the epochal, of an age coming to an end. The Theban tradition we have been discussing is no less lavish in its provision of images of violent death, but it deploys them to significantly different effect. The Two Noble Kinsmen is not, in the end, a particularly apt text from which to read any significant contrast between an authentic medieval chivalry and its ersatz early modern counterpart. Its very point resides in the sense of being unable to place oneself outside the circles of mourning it describes.

"We cannot," writes Fredric Jameson, "not periodize." 39 Periodization presents us with an apparently inexhaustible fund of intellectual embarrassment: so glaringly a construction after the fact, so immovably central to our sense of what the practice of history involves. Nor is its effect neutral. As a number of recent studies that attempt to rethink the medieval/early modern divide have shown, specific periodizing terms have a demonstrably distorting effect on the objects of enquiry that they frame. ${ }^{40}$ And yet, as Margreta de Grazia notes in a stimulating discussion of these issues, "it is hard to know what to do about the dilemma other than to point it out." 41 As Jameson recognizes, a flat refusal to engage with periodization simply results in a sort of return of the narrative repressed, this time with its structuring assumptions all the more insidiously effective for not being openly stated.

One way of coming to grips with the problem might start with the proposition that a distinction such as "the Middle Ages" versus "the early 
modern" carries no conviction in itself. It is virtually contentless: little more than a capsule formed by the dates indicating proposed upper and lower limits for the periods in question. If it is persuasive, it is because of the mutually self-constituting maneuver in which it both structures and is structured by an array of micronarratives through which our sense of period is focused and articulated. And it is these networks of smaller narratives (although, in truth, still rather grandes) that do possess a specificity with which one might profitably engage. The death of feudalism. The birth of capitalism. The development of the nation state. The rise of the individual. The rebirth of classical culture. The death of chivalry and the sense of the past. It is our feeling that these narratives are importantly explained by the period division between medieval and early modern that in turn bestows a persuasive animation upon that distinction, that makes it "rounded," like a well-drawn Forsterian character. In this positive feedback loop is located periodization's technology of verisimilitude.

To train one's sights on periodizing terms in themselves is in a sense pointless, then. They are simply too empty to sustain attack. Instead, one might seek to go beneath them, to burrow into the narrative subsoil in which they are rooted - ultimately perhaps to produce, if not a grammar, then at least an ordered catalogue of the tropes and figures that focalize our sense of historical progress even while they are distorted by it. That is what this essay has attempted to do. Part of the interest of a play like The Two Noble Kinsmen consists of the way it lies both within and outside of the reach of two of the narratives that bestow characterological depth upon our sense of what it means to be early modern as opposed to medieval: the death of chivalry and the Renaissance sense of the past. These seem obvious, almost inevitable, structures of interpretation to apply to the play in an attempt to grasp its essence. Looked at another way, though, the Two Noble Kinsmen might provide a platform from which to begin the work of disassembling these interpretative structures from the inside.

In the play, the representation of historical sequence is displaced into a thematics of literary imitation that is entirely unconcerned by the boundary between medieval and early modern. Its peculiar format, its adaptation of the poem by the honored ancestor that itself, as Warton noted, frames the past in a rather curious way, allows The Two Noble Kinsmen to sidestep the requirements both of a classicizing approach to the antique (we still have knights in Athens) and of a self-conscious medievalism (there is no sense of the play looking down its nose at the medieval way of representing the past, or even that it is identified as such). ${ }^{42}$ The layering of one period 
over another means that, even if they are perceived as clearly distinct epochs, neither can be safely declared dead, and the double removal of the play from the present actually neutralizes some of the more obvious forms of historical nostalgia.

The Two Noble Kinsmen is no less a product of the early seventeenth century for all this, of course. But perhaps in this way our sense of the palpable grip of our periodizing paradigm might begin to loosen somewhat, even as the narrative bones and sinews that constitute its anatomy become ever more visible. As the architectures of viewing and contextualization of The Two Noble Kinsmen itself suggest, the first step in liberating oneself from a given ideological — or intellectual — framework is to be able to see it as such.

\section{Notes}

I would like to thank the editors of this volume and its anonymous reader for their exceptionally acute and helpful comments on the earlier drafts of this essay.

1 Thomas Warton, The History of English Poetry, 4 vols. (London, 1774-81), 1:367.

2 "Renaissance" and "early modern," of course, invoke rather different understandings of the period in question, even if they do tend to articulate themselves in relation to the medieval in structurally similar ways. But since I am engaging with a tradition of attempting to define the historical distinctiveness of "the Renaissance" that continues to influence recent readings of "early modern" culture, I have used both terms in this essay.

3 Peter Burke, The Renaissance (London: Longmans, 1964), 2.

4 See Theodore E. Mommsen, "Petrarch's Conception of the 'Dark Ages,'” Speculum 17 (1942): 226-42; Herbert Weisinger, "The Self-Awareness of the Renaissance as a Criterion of the Renaissance," Papers of the Michigan Academy of Science, Arts, and Literature 19 (1944): 561-67; Erwin Panofsky, Renaissance and Renascences in Western Art (1960; repr. New York: Harper and Row, 1972). More recently, there is Thomas Greene's The Light in Troy: Imitation and Discovery in Renaissance Poetry (New Haven, Conn.: Yale University Press, 1982). These are brilliant and groundbreaking studies, but their cumulative effect is a tendency to assume that our period classifications are operative in a given early modern text, rather than to make the question of whether they are or not the starting point of enquiry. Contrast Ruth Morse, "Shakespeare's Ages," Shakespeare Survey 59 (2006): 254-66, who concludes that "[t]ime passes, and Shakespeare writes about its passage, but he did not, because he could not, share our concept of 'the middle ages'” (266). My study is in broad agreement with her. For Chaucer's engagements with the classical past, see A. J. Minnis, Chaucer and Pagan Antiquity (Cambridge: D. S. Brewer; Totowa, N.J.: Rowman and Littlefield, 1982). 
5 For the classic statement of this view, see Arthur Ferguson, The Indian Summer of English Chivalry (Durham, N.C.: Duke University Press, 1960). Again, this is a paradigm that retains a residual grip on thinking about the period, despite influential studies such as Richard McCoy's The Rites of Knighthood: The Literature and Politics of Elizabethan Chivalry (Berkeley: University of California Press, 1989); and Mervyn James's Society, Politics, and Culture: Studies in Early Modern England (Cambridge: Cambridge University Press, 1986). I have written at length about the use of the image of chivalry to construct the difference between the medieval and the early modern in Chivalry and Romance in the English Renaissance (Cambridge: D. S. Brewer, 2003), while my analysis of the tradition of focusing on the Renaissance sense of the past as constitutive of the period itself is developed at greater length in Renaissance Historical Fiction (forthcoming). In a sense, then, this essay attempts to lock together two arguments I have pursued elsewhere.

6 Panofsky, Renaissance and Renascences, 113.

7 Gordon McMullan and David Matthews, eds., introduction to Reading the Medieval in Early Modern England (Cambridge: Cambridge University Press, 2007), 2.

8 The Two Noble Kinsmen, prologue, 11-21. Unless otherwise indicated, references throughout are to William Shakespeare, The Complete Works, ed. Stanley Wells, Gary Taylor, John Jowett, and William Montgomery (Oxford: Clarendon Press, 2005).

9 Pericles 1.1-11 (for textual reasons, the Oxford Complete Works gives only scene and line numbers for this play). For a discussion of archaizing devices in Gower's speech, see Morse “Shakespeare's Ages," 259. Morse's main point is in fact that this does not mean that Gower's prologue perfectly reproduces our modern period construction; but it does travel further toward it than the equivalent passages in The Two Noble Kinsmen.

10 On this and other points, I am particularly indebted to Kathryn L. Lynch, "The Three Noble Kinsmen: Chaucer, Shakespeare, Fletcher," in Images of Matter: Essays on British Literature of the Middle Ages and Renaissance, ed. Yvonne Bruce (Newark: University of Delaware Press, 2005), 72-91. Lynch notes a possible allusion here to the Clerk's Tale (78-79). More generally, she provides a discussion of the relationship between Shakespeare and the "Theban" tradition I discuss, although her focus is less on its historiographical implications.

11 Chaucer, Workes, ed. Thomas Speght (London, 1598), “The Progenie of Geffrey Chaucer."

12 For discussions of the representation of the popular in early modern culture, see Annabel Patterson, Shakespeare and the Popular Voice (Oxford: Basil Blackwell, 1989); Mary Ellen Lamb, The Popular Culture of Shakespeare, Spenser, and Jonson (London: Routledge, 2006); and the essays collected in Neil Rhodes and Stuart Gillespie, eds., Shakespeare and Elizabethan Popular Culture (London: Arden Shakespeare, 2006).

13 See the discussion in Jeffrey Masten, Textual Intercourse: Collaboration, Authorship, and Sexualities in Renaissance Drama (Cambridge: Cambridge University Press, 1997), 56-60.

14 The Two Noble Kinsmen (London, 1634), sigs. D2r; for clarity, speech-prefixes have been spelled out, as is often done in the Quarto text itself. For a discussion of the staging of the scenes, see Lois Potter's edition of the play (London: Thompson, 1997), $63-64$. 
15 Given the play's interest in both toying with and unsettling the categories of the noble and the vulgar, it is significant that the Jailer's Daughter should immediately express a feeling of "pity" (2.1.22) for the imprisoned kinsmen, and that Hippolyta should echo her here, even if in such baroque terms. "Pitee" is, of course, the quintessentially "gentle" quality in the Knight's Tale and throughout Chaucer's work. See The Riverside Chaucer, ed. Larry D. Benson (New York: Oxford University Press, 1987): "pitee renneth soone in gentil herte" (I.1761 and n.). All further references are to this edition by fragment and line numbers for The Canterbury Tales, or by line numbers for other poems.

16 Henry Peacham, The Complete Gentleman (London, 1622), sig. B3v.

17 William Bird, The Magazine of Honour (London, 1642), sig. B2r.

18 Raphael Lyne in Shakespeare's Late Work (Oxford: Oxford University Press, 2007), 126, suggests a Fletcherian parody of The Tempest in the scene of the Jailer's Daughter's madness - a hint, perhaps, that her tale will not in fact end in death.

19 Given the literary allusions that frame her, it is something of a surprise that the Jailer's Daughter doesn't end up unpleasantly dead. Instead, she ends up unpleasantly alive - even if she doesn't realize it. Her insanity, and subsequent gulling into marriage, might constitute a sort of wry commentary on the tragicomic principle that (as Fletcher himself puts it) such a play "wants deaths, which is inough to make it no tragedie, yet brings some neere it, which is inough to make it no comedie." See The Faithfull Shepheardesse (London, 1610), "To the Reader." The seam of Shakespearean self-reference that runs through The Two Noble Kinsmen is naturally more prominent for us, but there may be a similar Fletcherian component to the play's self-consciousness.

20 Certainly the play's initial identification of its own rhetorical affectivity with a world of female experience might seem to open up the possibility of critique: encouraging us, for instance, to disapprove of something like Palamon's claim to have "[taken] possession" of Emilia "with mine eye" (2.2.170-71). David Wallace, in Chaucerian Polity: Absolutist Lineages and Associational Forms in England and Italy (Stanford, Calif.: Stanford University Press, 1997), 385-87, notes the telling shift from the fourteenth-century original, in which Palamon declares that "I loved hire first" (I.1146), to Shakespeare and Fletcher's "I saw her first" (2.2.161). The doubling seems very characteristic of the play's linguistic texture. Wallace, however, reads the moment differently, writing that in The Two Noble Kinsmen "the female body, divorced from time-honored recognition as rhetorical poetry incarnate, is remarked chiefly as the object of masculine sight and discovery." Indeed, glaring balefully out at the very end of his monumental attempt to reread the relationship between the medieval and the early modern, Palamon's gaze is positioned so as to assume a proleptic force in relation to a future history of dispossession and conquest. "As such," Wallace writes of the objectified female body, "it prepares the way for, becomes complicit with, the discovery of bodies further afield. Such bodies and such women will come to devise forms of resistance in new worlds quite different from, yet historically continuous with, that of Chaucer." The eye functions here as the organ through which early modern subjectivity will reach out and take possession of the world.

21 See Two Noble Kinsmen, ed. Potter, appendix 3.

22 See Potter's note to 2.3.63, and appendix 3. The play's sustained juxtaposition of high 
and low cultural forms might itself respond to a muted bifurcation in the early modern reception of Chaucer. For the most part, sixteenth-century commentary on Chaucer takes him as the model of courtly learning, and it is this figure that Shakespeare and Fletcher are responding to in the first instance. There are, however, repeated indications of a counter-tradition. George Whetstone, for instance, refers to Chaucer's “iests," and Robert Greene describes the Canterbury Tales as "broad enough before, and written homely and pleasantly"; qtd. in Chaucer: The Critical Heritage, ed. Derek Brewer, 2 vols. (London: Routledge and Kegan Paul, 1978), 1:114, 133. As Lee Patterson points out in Chaucer and the Subject of History (London: Routledge, 1991), 47-48, this is a dichotomy that has continued to structure responses to Chaucer's work down to the present day. For a discussion of A Midsummer Night's Dream as mediating Chaucer through the representation of popular culture, see Wallace, Chaucerian Polity, 119-24. Wallace argues for a greater distance between high and low in The Two Noble Kinsmen compared to the earlier play, of which it is in a sense a reworking. That needn't however detract from the perception that that distance is very much at stake in The Two Noble Kinsmen.

23 See James, Society, Politics, and Culture. One might even argue that the fascination with the spectacle of chivalry in The Two Noble Kinsmen is in its way as authentic a product of Shakespeare and Fletcher's humanistic training as are the canons of historical accuracy their play so conspicuously flouts. The humanist classroom offered its students an aspirational identity, a fantasy of social advancement grounded in the mastery of language and rhetoric. For that reason, as Anthony Grafton and Lisa Jardine (most notably) and others have argued — and for all its characteristic grumbling about entrenched cultures of feudal nobility - the ambition humanism encouraged was as much to join the dominant social order as it was to transform it. See Anthony Grafton and Lisa Jardine, From Humanism to the Humanities: Education and the Liberal Arts in Fifteenth-and Sixteenth-Century Europe (Cambridge, Mass.: Harvard University Press, 1986); and for a summary of these debates, see Rebecca W. Bushnell, A Culture of Teaching: Early Modern Humanism in Theory and Practice (Ithaca, N.Y.: Cornell University Press, 1996), 13-16. Bushnell's study represents an attempt to reclaim the humanist achievement as a socially transformative force.

24 Patterson, Chaucer and the Subject of History, 77 and 200 respectively. This essay aims to supplement Patterson's account, by noting that the "Theban" tradition he identifies does not end with the Middle Ages. It is appropriate, given the vision of history it adumbrates, that it should straddle the medieval and early modern period divide.

25 See the discussion in Patterson, Chaucer and the Subject of History, 63-64.

26 On the play in relation to themes of literary imitation and emulation, see Lynch, "Three Noble Kinsmen."

27 D. C. Feeney, The Gods in Epic: Poets and Critics of the Classical Tradition (Oxford: Clarendon Press, 1995), 339.

28 Lydgate's "Siege of Thebes," ed. Axel Erdmann and Eilert Ekwall, 2 vols. (London: Kegan Paul, Trench, Trübner, 1911-30). Further references are to this edition; I have not reproduced the editors' various diacritical and other marks. As Patterson, Chaucer and the Subject of History, 78-79, points out, the Siege of Thebes quotes from Anelida and Arcite, referring to lovers struck with "the poynt of remembraunce" (1488), a 
phrase Anelida uses twice (211, 350); and the notes to Erdmann and Ekwall's edition argue that Lydgate's apostrophe to Mars (2553) recalls the invocation of Chaucer's poem. The poem also quotes extensively from the Knight's Tale. James Simpson discusses Lydgate's Statian qualities and his poem's relationship to its vernacular sources, in “'Dysemol Daies and Fatal Houres': Lydgate's Destruction of Thebes and Chaucer's Knight's Tale," in The Long Fifteenth Century: Essays for Douglas Gray, ed. Helen Cooper and Sally Mapstone (Oxford: Clarendon Press, 1997), 15-49.

29 See Two Noble Kinsmen, ed. Potter, note to 4.2.104; and Chaucer, Workes, ed. Thomas Speght (London, 1602), in which Lydgate's poem is the last in the volume (sig. 3P1r), just as the Canterbury Tales is the first. It is, incidentally, both an index of his literary self-awareness, and something of a historical irony, that Lydgate should so comprehensively anticipate modern criticism's judgment of his botched assimilation of the Chaucerian literary achievement when he shows himself in his poem being accused - by Chaucer's Host, no less — of suffering from digestive problems (Siege of Thebes 113-18). Thanks to Ian Johnson for this point.

30 Narrative evasiveness and syntactical incompletion are persistent features of this tradition. Simpson, "Dysemol Daies and Fatal Houres," in Long Fifteenth Century, ed. Cooper and Mapstone, 24-25, notes the parallel paralipses in the culminating descriptions of funeral rites in Lydgate and Chaucer. The second of these nondescriptions incorporates an allusion to the funeral rites of Archemorus in Book 6 of the Thebaid, in which we read of the despoliation of a virgin forest in order to provide wood for the pyre. See Statius, Thebaid, Books I-VII, ed. and trans. D. R. Shackleton Bailey, 2 vols. (Cambridge, Mass.: Harvard University Press, 2003), VI.84-117; and compare the Knight's Tale, which proposes not to describe "hou the goddess ronnen up and doun, / Disinherited of hire habitacioun" (I.2925-26). For a Statian example of the paraliptic construction, see Thebaid IV.533-35; and the discussion in Feeney, The Gods in Epic, 342. For a stimulating analysis of such effects, see Philippa Hardman, "Lydgate's Uneasy Syntax," in John Lydgate: Poetry, Culture, and Lancastrian England, ed. James Simpson and Larry Scanlon (Notre Dame, Ind.: University of Notre Dame Press, 2006), 12-35.

31 Scott-Morgan Stalker, "Deference and Difference: Lydgate, Chaucer, and the Siege of Thebes," Review of English Studies 52 (2001): 20-21.

32 See Amy Appleford, "Shakespeare's Katherine of Aragon: Last Medieval Queen, First Recusant Martyr"; and Catherine Sanok, "Good King Henry and the Genealogy of Shakespeare's First History Plays," Journal of Medieval and Early Modern Studies 40 (2010): 149-72 and 37-63 respectively.

33 On the linguistic style of The Two Noble Kinsmen, see Russ McDonald, Shakespeare's Late Style (Cambridge: Cambridge University Press, 2006).

34 The Two Noble Kinsmen therefore retrospectively suggests a generic subtext to Hamlet's action. Sidney had already condemned the English stage's attempt to "match hornpipes and funerals"; An Apology for Poetry (or The Defence of Poesy), ed. R. W. Maslen (Manchester: Manchester University Press, 2002), 112. Shakespeare's depiction of the reign of Claudius maybe moves the argument beyond one of mere dramatic decorum into an exploration of the "politics of tragicomedy."

35 Patterson, Chaucer and the Subject of History, 65. 
36 Quoted in Fredric Jameson, A Singular Modernity: Essays on the Ontology of the Present (London: Verso, 2002), 24-25.

37 Patterson, Chaucer and the Subject of History, 60-61.

38 Thomas Malory, Works, ed. Eugène Vinaver (Oxford: Oxford University Press, 1971), $714,717$.

39 Jameson, A Singular Modernity, 29.

40 I am thinking in particular of Wallace's Chaucerian Polity; Reading the Medieval in Early Modern England, ed. McMullan and Matthews; and James Simpson's groundbreaking account in The Oxford English Literary History, Volume 2, 1350-1547: Reform and Cultural Revolution (Oxford: Oxford University Press, 2002).

41 Margreta de Grazia, "The Modern Divide: From Either Side," Journal of Medieval and Early Modern Studies 37 (2007): 463.

42 Is there no place at all in which the play frames its representation of Chaucer in terms of a logic of historical difference? Perhaps one. The morris dance of 3.5 is led by a rustic pedant, who, it might be argued, exists in an antithetical relationship to the Chaucer of the prologue. His misapplied erudition travesties Chaucer's genuine learning, and his presence on stage might be thought to incarnate the fears about vulgarization expressed in the prologue. As if to further raise the possibility of a connection, we have the presence in the morris dance of figures impersonating "Mine Host / And his fat Spouse" (3.5.129-30), and a couple of lines of densely alliterating verse ("And, dainty Duke, whose doughty dismal fame / From Dis to Daedalus ... / Is blown abroad" [3.5.116-18]) that might call to mind through contrast the protest of Chaucer's Parson, that "I kan nat geeste 'rum, ram, ruf,' by letter" (X.43). So it may be fitting that the Schoolmaster's speech should not be only marked by the heightened linguistic self-consciousness appropriate to his character, but that at least one point it should acquire a lightly archaized air, when we get references to a "mighty Moor — of mickle weight" (3.5.120; my emphasis). If the Schoolmaster travesties the Chaucer of the prologue, then the Chaucer of the prologue is being retroactively marked with the signs of linguistic difference. And if the Schoolmaster's troupe offers a reprise of the rustics of A Midsummer Night's Dream, and if Bottom and his fellows offer a reprise of the malapropisms of the narrator of the Tale of Sir Thopas, as David Wallace's Chaucerian Polity argues, 121, and since that narrator is a comedic self-portrait of Chaucer himself — then we have the same connection made again. 
